\title{
Atividade Cooperativa no Formato Jigsaw: Um Estudo no Ensino Superior de Química
}

\author{
(Jigsaw Cooperative Learning Technique: A Study in Undergraduate \\ Chemistry Teaching)
}

\section{DANIEL LINO TEODORO, PATRÍCIA FERNANDA DE OLIVEIRA CABRAL e SALETE LINHARES QUEIROZ}

Instituto de Química de São Carlos (IQSC - USP). (kafka@iqsc.usp.br, patriciacabral@iqsc.usp.br, salete@iqsc.usp.br)

Resumo. Desde o início da década de 1970, a discussão a respeito das formas de organização e da efetividade das atividades didáticas pautadas nos princípios da aprendizagem cooperativa vem se destacando em vários países. No presente trabalho aplicamos uma atividade didática de caráter cooperativo (formato jigsaw), em disciplina de comunicação científica oferecida a graduandos em química, na qual investigamos a dinâmica das interações estabelecidas entre os alunos, dentro dos seus respectivos grupos, a partir da análise das seguintes dimensões: funções de fala, processamento cognitivo e processamento social. As dimensões analisadas sugerem que a atividade mostrou-se efetiva, no que diz respeito ao desenvolvimento de condições para a aprendizagem cooperativa com foco no desenvolvimento de habilidades sociais, sem, no entanto, comprometer o aprendizado de conteúdos da disciplina. As percepções dos alunos com relação à atividade indicaram a sua boa receptividade.

Abstract. Since the beginning of the 70s, the discussion about ways of organization and effectiveness of learning activities based on cooperative learning has been growing in many countries. In the present work, we applied a didactic activity based on cooperative learning principles (jigsaw format) in a scientific communication course offered to undergraduate chemistry students. We investigated the dynamic of interactions among the students within the groups focusing on the following dimensions: verbal interactions, cognitive processing, and social processing. The dimensions analyzed suggest that the activity was effective in cooperative learning perspective without compromising the learning of the course contents. The students' perceptions indicated the success of the activity.

Palavras-chave: aprendizagem cooperativa, jigsaw, ensino de química

Keywords: cooperative learning, jigsaw, chemistry education

\section{Introdução}

Nas últimas décadas foram inúmeras as modificações realizadas nas grades curriculares dos cursos de graduação em química no Brasil. No entanto, conforme destacam as Diretrizes Curriculares Nacionais para os Cursos de Química, muitas delas limitaram-se à inclusão de novas disciplinas, extinção de outras ou apenas remanejamento das respectivas grades curriculares (ZUCCO et al., 1999; BRASIL, 2001). Infelizmente, poucas foram as modificações capazes de atender à necessidade advogada nas referidas Diretrizes de criação de

\footnotetext{
Um novo modelo de curso superior, que privilegie o papel e a importância do estudante no processo da aprendizagem, em que o papel do professor, de "ensinar coisas e soluções", passe a ser "ensinar o estudante a aprender coisas e soluções” (ZUCCO et al., 1999, p. 454).
}

No novo modelo, além da aprendizagem de conteúdos específicos, a escola tem a responsabilidade por uma formação mais geral do estudante, estando aí inseridas as 
questões que envolvem a cidadania. Nesse contexto, as estratégias didáticas de caráter cooperativo surgem como alternativa que pode auxiliar no alcance de tal formação, tornando o aluno parte mais ativa no processo de ensino-aprendizagem. Visando ao aprimoramento das habilidades sociais e tentando contribuir para o estabelecimento de um novo modelo de ensino, muitos pesquisadores da área de química (BARBOSA e JÓFILI, 2004; VALVERDE e VIZA, 2008; FATARELI et al., 2010; TEODORO et al., 2011; MASSI et al., 2013) vêm deixando seus registros sobre como trabalhar de forma cooperativa e propondo diretrizes para a execução de atividades dessa natureza. Os resultados reportados por eles levam a crer que a realização de atividades cooperativas pode favorecer o alcance de algumas das competências e habilidades apontadas como essenciais para a formação do químico, expressas nas Diretrizes Curriculares Nacionais.

Nessa perspectiva, no presente trabalho colocamos em funcionamento uma atividade didática pautada nos preceitos da aprendizagem cooperativa (formato jigsaw) em disciplina de comunicação científica, oferecida a alunos ingressantes de um Curso de Bacharelado em Química de uma universidade pública paulista. Temos como principal objetivo, investigar a dinâmica das interações estabelecidas entre os alunos, dentro dos seus respectivos grupos, a partir da análise das seguintes dimensões: funções de fala, processamento cognitivo e processamento social. Para tanto, nos baseamos no Modelo Analítico proposto por Kumpulainen e Mutanen (1999). Tendo em vista a natureza do presente artigo, apresentamos a seguir alguns dos fundamentos da aprendizagem cooperativa.

\section{Aprendizagem cooperativa}

Grandes contribuições para a divulgação da aprendizagem cooperativa são atribuídas aos autores David Johnson e Roger Johnson (1989). Uma característica chave que distingue esse tipo de aprendizagem da aprendizagem tradicional é a sua natureza social, pois os estudantes interagem, compartilham suas ideias e melhoram sua compreensão individual e mútua.

A aprendizagem cooperativa faz uso de pequenos grupos, assim possibilita que os estudantes trabalhem juntos para melhorar seu próprio aprendizado e dos demais. Seguindo a base teórica fornecida por Johnson et al. (1999), para que o trabalho cooperativo seja funcional e produtivo, as seguintes condições precisam estar presentes no processo de ensino-aprendizagem: 
- Interdependência positiva: o sentimento do trabalho conjunto para um objetivo comum em que cada um se preocupa com a aprendizagem dos colegas;

- Responsabilidade individual: cada elemento do grupo sente-se responsável pela sua própria aprendizagem e pela dos colegas e contribui com o grupo;

- Interação face-a-face: oportunidade de interagir com os colegas de modo a explicar, elaborar e relacionar conteúdos;

- Habilidades interpessoais: competências de comunicação, confiança, liderança, decisão e resolução de conflito;

- Processamento grupal: balanços regulares e sistemáticos do funcionamento do grupo e da progressão nas aprendizagens.

O domínio e a aplicação dos referidos componentes permitem que o docente planeje e organize as atividades cooperativas, nas quais os alunos trabalham juntos, por um dia ou por várias semanas, realizam tarefas que podem implicar, por exemplo, na solução de um problema, na redação de um relatório ou na leitura de um livro. Dentre as decisões prévias à realização da atividade que o docente necessita tomar tem sido digna de nota a questão sobre a distribuição dos alunos em grupos. É sugerido que grupos homogêneos são recomendáveis quando se procura promover o domínio de habilidades específicas ou o alcance de certos objetivos educativos em comum. Porém, em geral, nos grupos heterogêneos os alunos dão e recebem explicações mais frequentemente e levam em conta uma perspectiva mais ampla ao discutir a questão em foco na tarefa solicitada pelo professor, o que acentua a profundidade da compreensão e a qualidade do raciocínio (JOHNSON et al., 1999).

Diferentes métodos de aplicação, baseados nos preceitos da aprendizagem cooperativa, foram desenvolvidos e são objetos de extensa investigação (COCHITO, 2004), dentre os quais se destacam: a Instrução Complexa, o TGT (Teams-GamesTournament), o STAD (Student Teams Achievement Division) e o jigsaw. Cada método apresenta suas peculiaridades e a escolha de um ou de outro, depende do objetivo do docente e da disciplina. 
O método jigsaw, que fundamentou a elaboração da atividade didática descrita neste trabalho, foi desenvolvido por Aronson (1978). Este pode ser definido como um conjunto de procedimentos específicos que se adequam ao desenvolvimento de competências cognitivas de nível superior e não se distancia dos princípios fundamentais considerados pelos irmãos Johnson (JOHNSON et al., 1999). Nesse método, os alunos trabalham em grupos cooperativos, sendo que o trabalho que cada aluno realiza é essencial para a concretização do trabalho final do grupo e a sua sistemática de funcionamento assemelha-se a de um quebra-cabeça. Daí a origem do nome jigsaw, que somente está concluído quando todas as peças estão encaixadas. Um esquema da formação dos grupos encontra-se ilustrado na Figura 1.

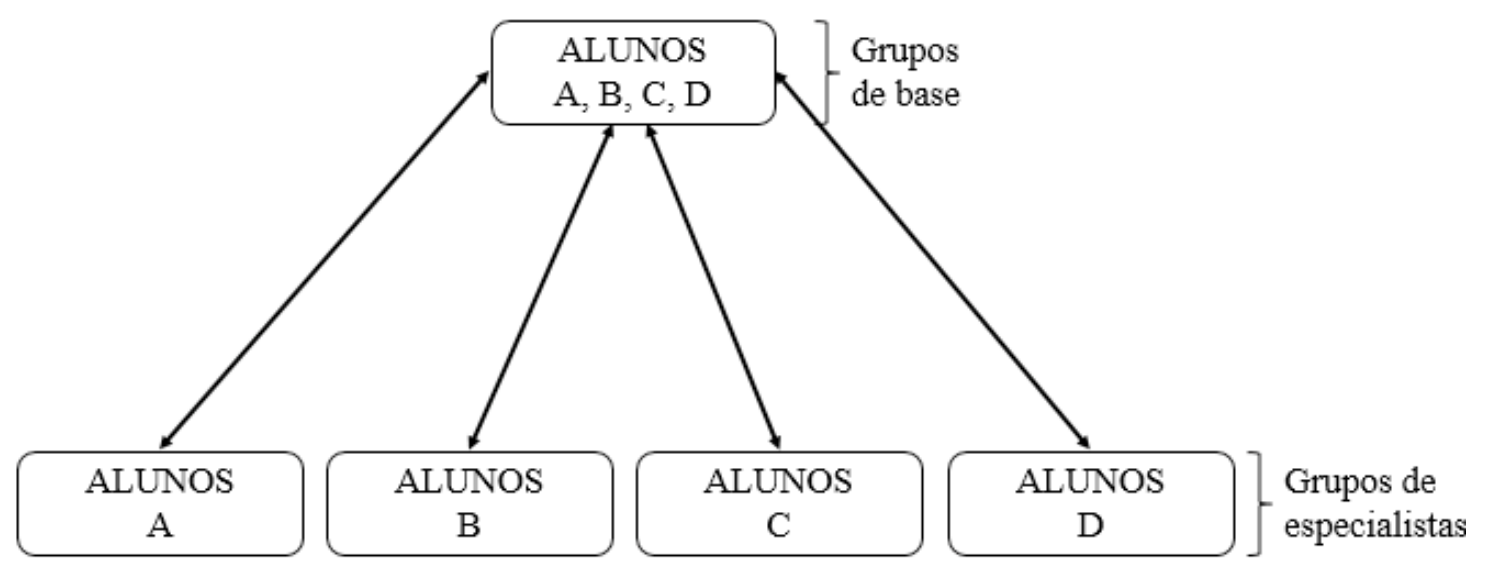

Figura 1 - Esquema da formação de pequenos grupos de discussão pelo método jigsaw adaptado de Barbosa e Jófili (2004). Existe apenas um grupo de origem, formado por alunos A, B, C e D (grupo de base). Existem 4 subgrupos, que são formados por alunos A, B, C ou D (grupos de especialistas). As setas indicam a movimentação dos alunos nos grupos: todos são provenientes do grupo de origem e para ele retornam, na etapa final da atividade.

Na primeira fase da atividade os alunos são distribuídos em grupos de base heterogêneos. O material acadêmico é dividido em pequenas partes e cada membro do grupo é designado a estudar apenas uma delas. Na segunda fase, os alunos de grupos de bases diferentes que foram designados a estudar a mesma parte do material didático, estudam e discutem seus materiais juntos, formando grupos de especialistas. Na terceira fase, depois da discussão nos grupos de especialistas, cada aluno retorna ao seu grupo de base e compartilha o aprendizado adquirido sobre sua parte com os outros membros do seu grupo.

\section{Referencial teórico: Modelo Analítico de Kumpulainen e Mutanen}

O Modelo Analítico proposto por Kumpulainen e Mutanen (1999) tem como objetivo principal investigar a natureza das atividades sociais dos alunos, em especial as 
interações verbais realizadas em diferentes situações de aprendizagem. Inicialmente o Modelo foi desenvolvido para analisar interações verbais entre pares de alunos e também com os professores (FOURLAS e WRAY, 1990). Posteriormente foi testado, modificado e aplicado em um estudo que investigava as atividades sociais ocorridas entre os alunos durante um processo de escrita colaborativa (KUMPULAINEN, 1994). Nesse contexto, o Modelo foi usado com o objetivo de demonstrar as estruturas e a qualidade das interações e, apesar de mostrar potencial de análise, ainda não estava pronto para desvendar as complexidades do processo de aprendizagem social compartilhada.

Pensando nisso, os autores resolveram buscar um sistema de análise descritiva com uma perspectiva mais holística e multidimensional, o que exigia um Modelo que não fosse focado apenas nas interações verbais e que proporcionasse entendimento sobre a construção do conhecimento, valorizando o caráter da atividade, momento a momento, tomando como foco de análise o aluno e o grupo.

Os interesses acima descritos levaram à formulação do Modelo por nós utilizado, que descreve a dinâmica das interações estabelecidas entre os estudantes, envolvendo cada uma das 3 dimensões: funções de fala, processamento cognitivo e processamento social.

\section{Primeira dimensão: funções de fala}

No que diz respeito à primeira dimensão, são investigadas as estratégias comunicativas adotadas pelos alunos enquanto interagem com os colegas, buscando determinar quais são os significados funcionais das suas falas. Funções de fala podem refletir as expectativas dos alunos frente ao contexto didático proposto pelo professor e permitem interpretar a evolução da situação criada pela atividade.

O Quadro 1 ilustra as funções de fala, adaptadas para a nossa análise, a partir do trabalho de Kumpulainen e Mutanen (1999). 
Quadro 1 - Categorização e descrição das funções de fala (adaptação do trabalho de Kumpulainen e Mutanen (1999).

\begin{tabular}{|c|c|}
\hline Categorias & Descrição \\
\hline $\begin{array}{l}\text { Interrogação } \\
\text { (Int) }\end{array}$ & $\begin{array}{l}\text { É caracterizada quando o aluno elabora uma questão ou faz referência a uma } \\
\text { questão feita pelo professor ou por outro membro do grupo. }\end{array}$ \\
\hline $\begin{array}{l}\text { Resposta direta } \\
\text { (Res) }\end{array}$ & $\begin{array}{l}\text { É caracterizada quando a fala do aluno busca responder uma pergunta dita } \\
\text { anteriormente de forma simples e objetiva. }\end{array}$ \\
\hline $\begin{array}{l}\text { Resposta crítica } \\
\text { (Res-C) }\end{array}$ & $\begin{array}{c}\text { É caracterizada quando a resposta do aluno parte de uma análise mais aprofundada } \\
\text { e elaborada. }\end{array}$ \\
\hline $\begin{array}{l}\text { Informação } \\
\text { (Inf) }\end{array}$ & $\begin{array}{c}\text { É caracterizada quando ocorre o fornecimento de informação, desde que essa } \\
\text { informação não tenha como objetivo responder uma pergunta ou organizar ideia } \\
\text { ou ação. }\end{array}$ \\
\hline $\begin{array}{l}\text { Leitura em voz } \\
\text { alta } \\
\text { (LVA) }\end{array}$ & $\begin{array}{c}\text { É caracterizada pela leitura de um material em voz alta. Seja esse material } \\
\text { produzido pelo leitor, por outro membro do grupo ou por terceiros. }\end{array}$ \\
\hline $\begin{array}{l}\text { Organização de } \\
\text { ação } \\
(\text { Org-A) }\end{array}$ & $\begin{array}{c}\text { É caracterizada quando a fala do aluno tem o objetivo de organizar o grupo ou a } \\
\text { atividade. }\end{array}$ \\
\hline $\begin{array}{l}\text { Experiencial } \\
\text { (Exp) }\end{array}$ & É caracterizada quando ocorre uma fala relatando experiências pessoais. \\
\hline $\begin{array}{l}\text { De julgamento } \\
\text { (Jul) }\end{array}$ & $\begin{array}{l}\text { É caracterizada quando as falas buscam concordar ou discordar com ações ou } \\
\text { ideias dos demais membros do grupo. }\end{array}$ \\
\hline $\begin{array}{l}\text { Avaliação } \\
\text { (Ava) }\end{array}$ & $\begin{array}{l}\text { É caracterizada quando o aluno faz uma avaliação de uma ação ou ideia que tenha } \\
\text { partido do grupo ou de um membro do grupo. }\end{array}$ \\
\hline $\begin{array}{l}\text { Afetiva } \\
\text { (Afe) }\end{array}$ & É caracterizada quando ocorre expressão de sentimentos. \\
\hline $\begin{array}{l}\text { Citação crítica } \\
\text { (Cit-C) }\end{array}$ & É caracterizada quando o aluno tenta justificar ou refutar ideias ou ações. \\
\hline $\begin{array}{l}\text { Organização de } \\
\text { ideia } \\
(\text { Org-I })\end{array}$ & $\begin{array}{l}\text { É caracterizada quando a fala do aluno tem o objetivo de organizar as ideias } \\
\text { expostas buscando a melhor resposta. }\end{array}$ \\
\hline $\begin{array}{l}\text { Complemento de } \\
\text { resposta } \\
(\mathrm{C}-\mathrm{Res})\end{array}$ & $\begin{array}{l}\text { É caracterizada por falas que complementam sentidos de respostas dadas } \\
\text { anteriormente. }\end{array}$ \\
\hline $\begin{array}{l}\text { Inclassificável } \\
\text { (Inc) }\end{array}$ & É caracterizada por funções que não podem ser classificadas nas demais funções. \\
\hline
\end{tabular}

\section{Segunda dimensão: processamento cognitivo}

No que diz respeito à segunda dimensão, são investigadas as estratégias adotadas pelos alunos, do ponto de vista cognitivo, na resolução da tarefa solicitada (Quadro 2).

Quadro 2 - Categorização e descrição dos processamentos cognitivos (adaptação do trabalho de Kumpulainen e Mutanen (1999)).

\begin{tabular}{|c|c|}
\hline Categorias & Descrição \\
\hline $\begin{array}{l}\text { Procedural } \\
\text { (PCR) }\end{array}$ & $\begin{array}{c}\text { Atividade rotineira, que exige apenas a manipulação, organização e execução de } \\
\text { tarefas sem análise reflexiva. }\end{array}$ \\
\hline Off-task (PCO) & Atividade não relacionada à tarefa solicitada pelo professor. \\
\hline $\begin{array}{l}\text { Interpretativo ou } \\
\text { Exploratório } \\
\text { (PCE) }\end{array}$ & $\begin{array}{l}\text { Atividade crítica e exploratória, que inclui planejamento, levantamento de hipóteses, } \\
\text { avaliação e experimentação. }\end{array}$ \\
\hline
\end{tabular}




\section{Terceira dimensão: processamento social}

No que diz respeito à terceira dimensão, são investigadas as relações sociais estabelecidas entre os alunos e, para tanto, é considerado o modo de interação predominante em um intervalo de tempo: competitivo, dominante, individualista, colaborativo, argumentativo, tutorial e modo conflitante. As seguintes adaptações fizeram-se necessárias com relação a essa dimensão, com o intuito de adequá-la a uma atividade de grupo com número superior a 2 componentes. Além das diferenças no número de alunos, em nossa atividade, de forma distinta da original, ocorria a interação entre os alunos e o docente, o que nos fez modificar a categoria tutorial para que esta se adequasse à nova realidade.

Dessa forma, consideramos que as interações podem ser basicamente dos seguintes tipos: colaborativo (caracterizado pela igual participação dos membros do grupo na realização das tarefas) e tutorial (caracterizado pelo auxílio prestado por um estudante ou professor a outro membro na realização da tarefa). O processamento social do tipo individualista pode ser caracterizado pelo trabalho individual, sem compartilhamento das dúvidas e conclusões com os demais membros do grupo, ou pelo domínio de um dos membros na realização da tarefa. O processamento social do tipo confuso pode ser caracterizado pela ocorrência de conflitos sociais ou acadêmicos não solucionados. O processamento social do tipo nulo é caracterizado pela falta de compreensão entre os alunos ou da própria tarefa.

\section{Percurso metodológico}

A atividade didática foi aplicada em disciplina de comunicação científica, oferecida a alunos ingressantes de um Curso de Bacharelado em Química de uma universidade pública paulista. A disciplina, de caráter obrigatório, ministrada em 2 horas semanais, visa à discussão das diversas formas como a ciência é divulgada, a apresentação aos estudantes de alguns tipos de documentos científicos e suas características peculiares, assim como de fontes de informação em ciência e tecnologia. Tradicionalmente, esta é oferecida a partir da realização de aulas expositivas, de trabalhos em grupo e de aulas práticas na biblioteca.

No primeiro dia de aula, a disciplina contava com 51 alunos matriculados e ao final do semestre com 62, os 11 alunos adicionais juntaram-se à turma, devido às chamadas subsequentes à primeira chamada do vestibular. Os 51 alunos, inicialmente engajados na disciplina, foram distribuídos em grupos cooperativos heterogêneos, uma 
vez que responderam a um questionário de caracterização que subsidiou a sua distribuição nos grupos. Os demais alunos não participaram da etapa de formação dos grupos heterogêneos, porém participaram das atividades cooperativas.

Os alunos foram divididos em 12 grupos, 10 grupos heterogêneos de 5 membros e 2 grupos de 6 membros não heterogêneos. Selecionamos aleatoriamente 5 grupos heterogêneos, acompanhamos suas atividades e registramos seus diálogos em áudio. Nessa perspectiva, apenas 25 alunos foram tomados como sujeitos na investigação das interações estabelecidas nas atividades realizadas no modelo cooperativo jigsaw.

Para que a atividade didática fosse levada a cabo, o cumprimento das seguintes etapas fez-se necessário:

Formação dos grupos heterogêneos (Etapa 1): os grupos heterogêneos foram formados com base na aplicação de um questionário de caracterização preenchido pelos alunos no primeiro dia de aula. Este era constituído por 30 questões concernentes à formação estudantil dos alunos, habilidade de escrita e motivação pela leitura.

Aulas iniciais expositivas dialogadas (Etapa 2): ainda no primeiro dia de aula, o docente fez uma apresentação geral sobre a disciplina, informando o conteúdo a ser ministrado. No segundo dia de aula, os alunos conheceram as distribuições dos grupos de base e assistiram a uma aula com foco especial no funcionamento do método jigsaw. A apresentação teve como objetivo dar conhecimento aos alunos sobre a metodologia e explicar como seria aplicada, assim como sanar possíveis dúvidas. Em seguida, o docente indicou uma referência completa de cada um dos seguintes tipos de documentos que deveriam ser trazidos pelos membros dos grupos de base para a aula seguinte: artigo científico original de pesquisa, artigo de revisão, artigo de divulgação científica, artigo de educação em química, tese ou dissertação.

Aula pautada no trabalho dos grupos de base - primeira atividade (Etapa 3): no terceiro dia de aula os alunos reuniram-se nos grupos de base, cada aluno com seu respectivo documento. Assim, cada grupo constituído por 5 alunos detinha um tipo de cada um dos documentos solicitados pelo docente, como apresentado na Figura 2. Para a realização da atividade foi entregue aos alunos um questionário relativo aos documentos que o grupo tinha em mãos. $\mathrm{O}$ objetivo do questionário foi buscar uma resposta coletiva dos alunos sobre as características dos diferentes documentos. 
Grupos de Base

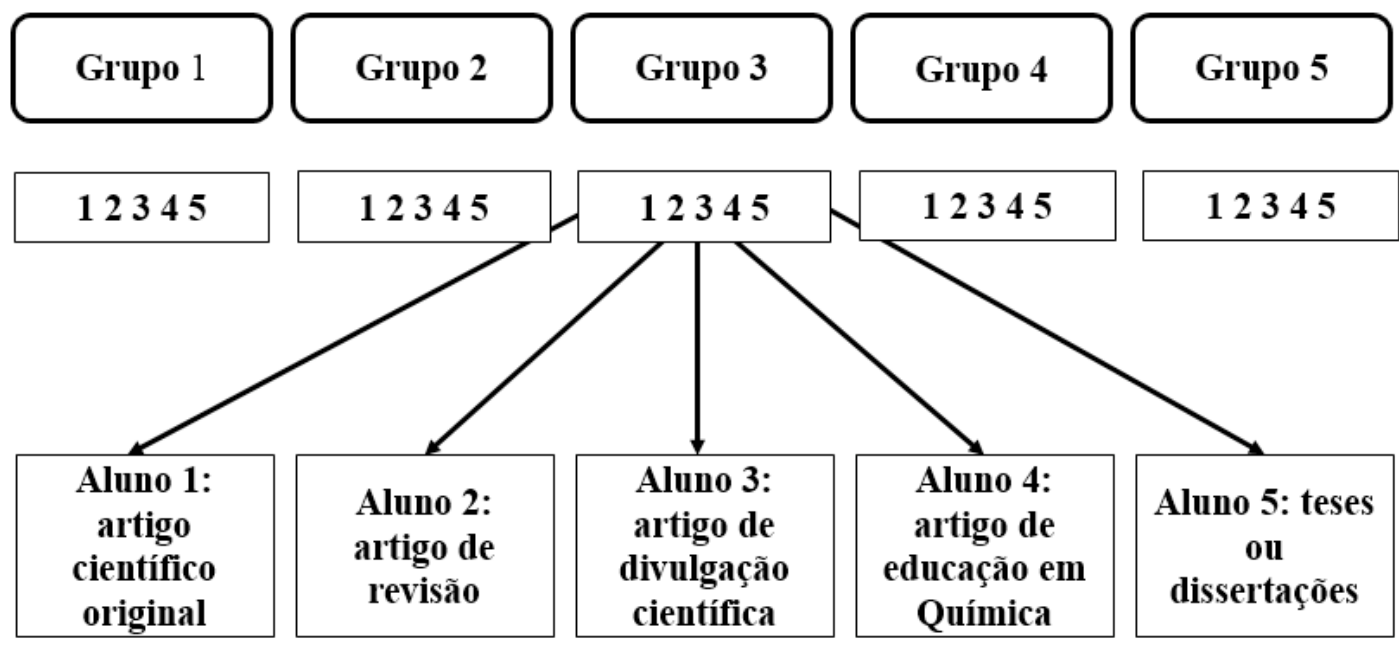

Figura 2 - Apresentação dos grupos de base, cada grupo composto por 5 alunos, cada um com um tipo de documento.

No grupo de base, cada aluno era responsável por exercer uma das seguintes funções: facilitador (garantir que todos os membros tivessem chance de contribuir para a realização da atividade); relator (expor os resultados da discussão); redator (redigir respostas elaboradas pelo grupo); porta-voz (intermediar a relação dos alunos com o professor); mediador/gestor de recursos (manter as interações entre os membros harmoniosas e tornar acessíveis os materiais necessários para o trabalho). Ao final da atividade, os alunos realizaram o processamento grupal. Ao final da aula foram incumbidos de realizar, individualmente, uma atividade extraclasse, com questões relacionadas às características estruturais dos seus respectivos documentos.

Aula pautada no trabalho dos grupos de especialistas (Etapa 4): no quarto dia de aula, os alunos de grupos de base diferentes, mas que foram designados a estudar o mesmo documento, discutiram sobre os seus documentos específicos em um novo grupo (denominado grupo de especialistas). Assim, por exemplo, os alunos especialistas em artigos de divulgação científica investigaram características comuns a textos desse tipo, porém provenientes de revistas distintas, conforme ilustra a Figura 3. 


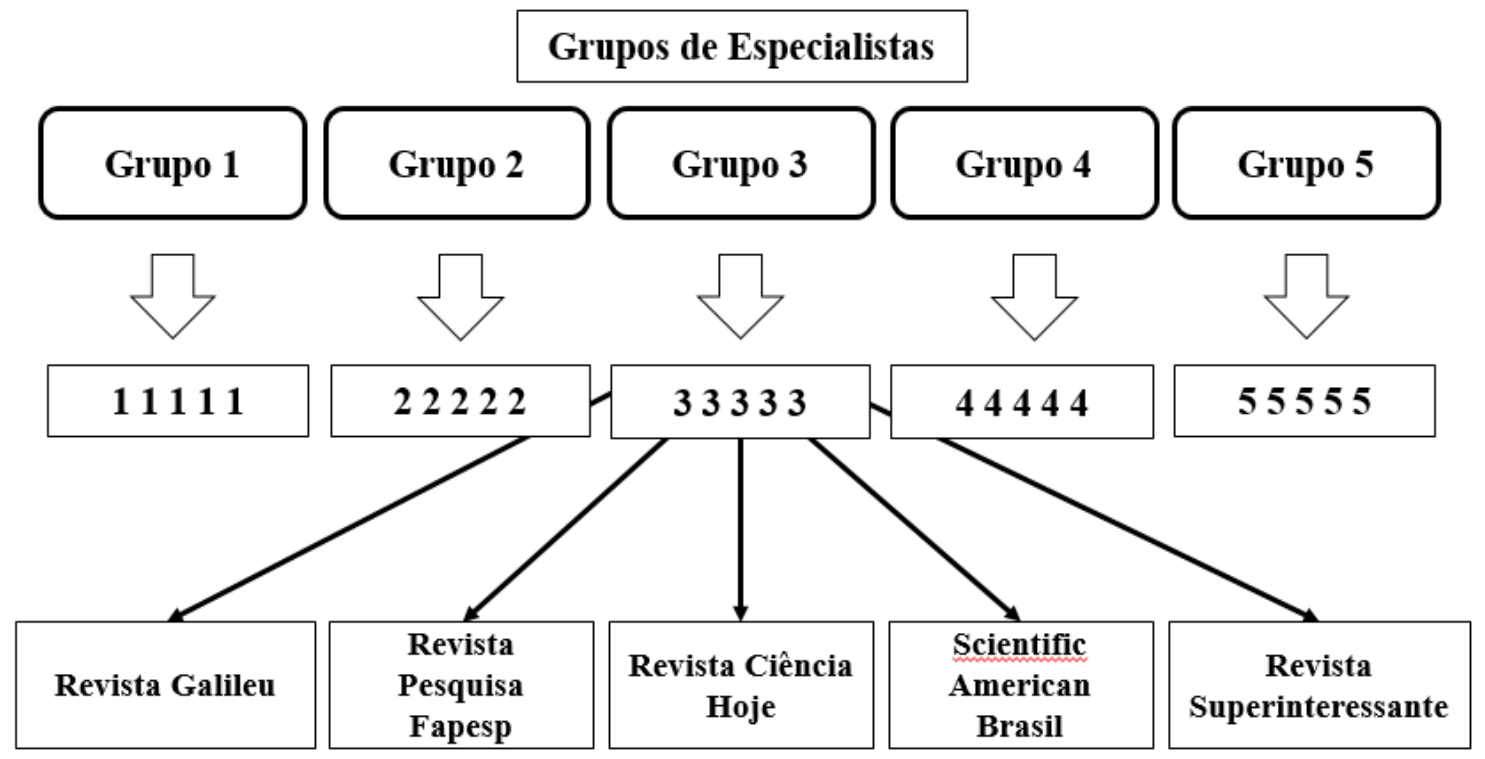

Figura 3 - Constituição do grupo de especialistas em artigos de divulgação científica.

$\mathrm{Na}$ ocasião, o docente entregou uma nova atividade, a partir da qual os alunos tiveram um contato mais aprofundado sobre as características do seu documento específico. Cada aluno apresentou as respostas dadas para atividade extraclasse e, após uma discussão, o grupo chegou a um consenso sobre a melhor resposta, desenvolvendo um texto sobre o documento estudado.

Aula pautada no trabalho dos grupos de base - segunda atividade (Etapa 5): no quinto dia de aula, os alunos dos grupos de especialistas retornaram aos seus grupos de base e compartilharam com os demais alunos o conhecimento adquirido. Além disso, cada aluno tinha em mãos um texto organizado sobre seu documento e, a partir dessa nova perspectiva, aprimoraram as questões produzidas na atividade inicial solicitada aos grupos de base, agora munidos de uma visão privilegiada sobre a totalidade dos documentos. Assim, no final da realização do jigsaw, todos os membros dos grupos entraram em contato com todo o conteúdo. Ao final dessa atividade, os alunos realizaram novamente o processamento grupal.

Uma vez concluído o jigsaw, os alunos responderam a um questionário, elaborado com base no trabalho de Eilks (2005). O referido questionário foi aplicado com o intuito de conhecer as impressões dos alunos sobre a atividade didática.

\section{Resultados e discussão}

Com o objetivo de investigar as interações ocorridas durante as atividades realizadas, procuramos classificar as transcrições das falas de todos os participantes dos 
grupos de acordo com as dimensões propostas por Kumpulainen e Mutanen (1999). Desse modo, construímos mapas analíticos nos moldes ilustrados no Quadro 3, sendo que este referente à primeira atividade do grupo de base, realizada pelo Grupo 1. Nele temos 2 unidades de análise, a primeira, chamada de unidade de mensagem, é referente a uma exposição verbal que possa representar uma mensagem; a segunda unidade é marcada por períodos de tempo determinados de 2 minutos. Cada unidade de mensagem é numerada e classificada na primeira dimensão (função de fala) e na segunda dimensão (processamento cognitivo). A segunda unidade de análise é relacionada à terceira dimensão (processamento social). Os fragmentos proferidos pelo docente foram transcritos, entretanto, não foram classificados. Assim, o Quadro 3 exemplifica como o mapa foi construído para cada um dos grupos, permitindo a organização e a análise dos dados.

Quadro 3 - Trechos do mapa analítico das interações ocorridas no Grupo 1.

\begin{tabular}{|c|c|c|c|c|}
\hline $\begin{array}{l}\text { Unidade de } \\
\text { mensagem }\end{array}$ & $\begin{array}{l}\text { Função } \\
\text { de fala }\end{array}$ & Fragmentos da transcrição & $\begin{array}{l}\text { Processo } \\
\text { cognitivo }\end{array}$ & Agente \\
\hline 145 & Int & É a questão 1 , já está feita? & PCR & A2 \\
\hline 146 & Int & Vocês viram isso? & PCE & $\mathrm{A} 3$ \\
\hline 147 & Inf & No Caribe eles tiram. & PCE & A3 \\
\hline 148 & Ava & Osmose reversa. É da hora isso! & PCE & A2 \\
\hline 149 & Inf & $\begin{array}{l}\text { No Caribe eles tiram muita água. No Caribe não, no } \\
\text { Iraque, Oriente Médio. }\end{array}$ & PCE & A3 \\
\hline 150 & Cit-C & Também lá é tudo deserto, tem que tirar muita água. & PCE & $\mathrm{A} 2$ \\
\hline 151 & Inf & Vinte bilhões de litros de água. & PCE & $\mathrm{A} 3$ \\
\hline 152 & Inf & Por dia, caramba! & PCE & A2 \\
\hline 153 & Cit-C & $\begin{array}{l}\text { É bom tirar mesmo porque em vintes anos a água vai } \\
\text { entrar em crise igual a do petróleo de } 1973 \text {. }\end{array}$ & PCE & A2 \\
\hline 154 & Ava & É muita coisa. & PCE & A3 \\
\hline 155 & Cit-C & $\begin{array}{l}\text { É muita pensando em número, porque se pensar em } \\
\text { população... }\end{array}$ & PCE & A2 \\
\hline 156 & Int & O seu (artigo) é do que? & PCR & A4 \\
\hline 157 & Res & Divulgação. & PCR & A3 \\
\hline 158 & Int & $\begin{array}{c}\text { O seu é sobre cristalização, água doce que vem do } \\
\text { mar? }\end{array}$ & PCR & A2 \\
\hline 159 & Res & Isso. & PCR & A3 \\
\hline 160 & Ava & O meu é sobre água também. Legal. & PCR & $\mathrm{A} 2$ \\
\hline 161 & Inf & $\begin{array}{l}\text { Olha o meu aqui. Especialistas acreditam que em } \\
\text { vinte anos teremos uma crise semelhante a do } \\
\text { petróleo de } 73 \text {. }\end{array}$ & PCR & $\mathrm{A} 2$ \\
\hline 162 & Cit-C & $\begin{array}{c}\text { Vinte anos, sendo que a revista é de 2001, mas a } \\
\text { probabilidade era de vinte até trinta anos. De vinte a } \\
\text { vinte cinco anos. }\end{array}$ & PCE & A2 \\
\hline 163 & Inc & Também a água de hoje em dia. & PCR & A2 \\
\hline 164 & Int & Tem o volume, alguma coisa? & PCR & A4 \\
\hline 165 & Res & Embaixo da revista, normalmente. & PCR & $\mathrm{A} 2$ \\
\hline 166 & Res & Não tem volume. & PCR & A4 \\
\hline 167 & Int & Não tem volume? & PCR & $\mathrm{A} 3$ \\
\hline 168 & Int & Não tem? & PCR & A5 \\
\hline 169 & Org-A & Deixa eu anotar o nome da revista, então. & PCR & A4 \\
\hline Tempo & $2 \mathrm{~min}$ & Processamento social: Colaborativo & & \\
\hline
\end{tabular}

Int= interrogação; Res= resposta; Inf= informação; Org-A= organização de ação; $\mathrm{Ava}=$ avaliação; Cit-C= citação crítica; Inc= inclassificável; $\mathrm{PCR}=$ processamento cognitivo rotineiro; $\mathrm{PCE}=$ processamento cognitivo exploratório; $\mathrm{AX}=$ aluno $\mathrm{X}$, sendo $\mathrm{X}$ de 1 a 5 . 
Primeira dimensão: funções de fala

Distribuição das funções de fala nos grupos de base: primeira e segunda atividade

Com o intuito de deixar mais clara a análise com relação às funções de fala, distribuímos as mesmas em 3 blocos. O primeiro é composto pelas funções de fala do tipo interrogação (Int), resposta (Res), complemento de resposta (C-Res), informação (Inf) e leitura em voz alta (LVA), as quais refletem as interações ocorridas entre os interlocutores, principalmente, na perspectiva de busca de caminhos para a resolução da atividade proposta. O Quadro 4 apresenta trechos do mapa analítico da primeira atividade do Grupo 1, nos quais as funções de fala do primeiro bloco fazem-se presentes.

Quadro 4 - Trechos do mapa analítico das interações ocorridas no Grupo 1, exemplificando as funções de fala pertencentes ao primeiro bloco.

\begin{tabular}{|c|c|c|c|c|}
\hline $\begin{array}{c}\text { Unidade } \\
\text { de } \\
\text { mensagem }\end{array}$ & $\begin{array}{c}\text { Função } \\
\text { de fala }\end{array}$ & Fragmento 1 & $\begin{array}{c}\text { Processo } \\
\text { cognitivo }\end{array}$ & Agente \\
\hline 185 & Int & A tese de doutorado a gente não tem familiaridade. \\
Tem? & PCR & A5 \\
\hline 186 & Res & Não tem como. & PCR & A2 \\
\hline 187 & C-Res & A parte que é mais séria. & PCR & A5 \\
\hline 188 & Inf & $\begin{array}{c}\text { O meu artigo é da água. Todo mundo tem base, } \\
\text { ainda mais por causa da escassez que está vindo aí. }\end{array}$ & PCR & A2 \\
\hline $\begin{array}{c}\text { Unidade } \\
\text { de } \\
\text { Mensagem }\end{array}$ & $\begin{array}{c}\text { Função } \\
\text { de fala }\end{array}$ & Fragmento 2 & Processo & Agente \\
\hline 253 & Int & O artigo é eclético, dirigido a... É isso? & PCR & A4 \\
\hline 254 & $\begin{array}{c}\text { LVA- } \\
\text { Res }\end{array}$ & $\begin{array}{c}\text { Aqui está escrito assim: Artigo que relata resultado } \\
\text { original de pesquisa. }\end{array}$ & PCR & A1 \\
\hline
\end{tabular}

O segundo bloco é composto pelas funções de fala do tipo organização de ação (Org-A), experiencial (Exp), julgamento (Jul), avaliação (Ava) e afetiva (Afe). Essas funções são as que melhor refletem o grau de interação social ocorrida entre os interlocutores. O Quadro 5 apresenta trechos do mapa analítico da primeira e segunda atividade do Grupo 2, nos quais as funções de fala do segundo bloco fazem-se presentes. 
Quadro 5 - Trechos do mapa analítico das interações ocorridas no Grupo 2, exemplificando as funções de fala pertencentes ao segundo bloco.

\begin{tabular}{|c|c|c|c|c|}
\hline $\begin{array}{c}\text { Unidade } \\
\text { de } \\
\text { mensagem }\end{array}$ & $\begin{array}{c}\text { Função } \\
\text { de fala }\end{array}$ & Fragmento 1 & $\begin{array}{c}\text { Processo } \\
\text { cognitivo }\end{array}$ & Agente \\
\hline 65 & Org-A & E você passa para o final. & PCR & A2 \\
\hline 66 & Jul & Tudo bem, então. & PCR & A5 \\
\hline 67 & Afe & Tomara que você entenda a letra dele. & PCR & A4 \\
\hline 68 & Org-A & Então vai. & PCR & A4 \\
\hline $\begin{array}{c}\text { Unidade } \\
\text { de } \\
\text { mensagem }\end{array}$ & $\begin{array}{c}\text { Função } \\
\text { de fala }\end{array}$ & Fragmento 2 & Processo & Agente \\
\hline 295 & Exp & Eu tenho uma capacidade impressionante para essas & PCR & A2 \\
\hline 296 & Exp & Eu já errei meu nome no vestibular. & PCO & A4 \\
\hline $\begin{array}{c}\text { Unidade } \\
\text { de } \\
\text { mensagem }\end{array}$ & $\begin{array}{c}\text { Função } \\
\text { de fala }\end{array}$ & Fragmento 3 & Processo & Agente \\
\hline 607 & Ava & O texto está mais simples, menos cansativo para & PCR & A4 \\
\hline 608 & Jul & quem vai ler também. & PCR & A2 \\
\hline 609 & Ava & Eu acho. & PCR & A3 \\
\hline
\end{tabular}

O terceiro bloco é composto pelas funções de fala do tipo resposta crítica (ResC), citação crítica (Cit-C) e organização de ideia (Org-I). Essas funções exigem um alto grau de elaboração pessoal e são relacionadas diretamente ao desenvolvimento cognitivo dos alunos. O Quadro 6 apresenta trechos do mapa analítico da primeira atividade do Grupo 1, nos quais as funções de fala do terceiro bloco se fazem presentes. 
Quadro 6 - Trechos do mapa analítico das interações ocorridas no Grupo 1, exemplificando as funções de fala pertencentes ao terceiro bloco.

\begin{tabular}{|c|c|c|c|c|}
\hline $\begin{array}{l}\text { Unidade } \\
\text { de } \\
\text { mensagem }\end{array}$ & $\begin{array}{l}\text { Função } \\
\text { de fala }\end{array}$ & Fragmento 1 & $\begin{array}{l}\text { Processo } \\
\text { cognitivo }\end{array}$ & Agente \\
\hline 453 & Int & $\begin{array}{c}\text { Essa parte de artigo de educação, não é como se } \\
\text { fosse artigo de professor? }\end{array}$ & PCR & A1 \\
\hline 454 & Res-C & $\begin{array}{l}\text { Não só para o professor como para o aluno. Por isso } \\
\text { que a linguagem é mais simples e mais facilitada, } \\
\text { acho que o seu também dá para entender. }\end{array}$ & PCE & A2 \\
\hline $\begin{array}{l}\text { Unidade } \\
\text { de } \\
\text { mensagem }\end{array}$ & $\begin{array}{l}\text { Função } \\
\text { de fala }\end{array}$ & Fragmento 2 & $\begin{array}{l}\text { Processo } \\
\text { cognitivo }\end{array}$ & Agente \\
\hline 468 & Inf & Esse é o mais comum que aparece em revista. & PCR & A1 \\
\hline 469 & Org-I & $\begin{array}{l}\text { Tem que colocar isso: que os dois artigos, de } \\
\text { divulgação e de educação, são os que mais se } \\
\text { familiarizaram. O grupo inteiro se familiariza. }\end{array}$ & PCR & A4 \\
\hline 470 & Org-I & $\begin{array}{l}\text { Pode por também que são os mais abordados pela } \\
\text { mídia. E por isso têm uma maior probabilidade de } \\
\text { você entrar em contato com o assunto. }\end{array}$ & PCR & A2 \\
\hline $\begin{array}{c}\text { Unidade } \\
\text { de } \\
\text { mensagem }\end{array}$ & $\begin{array}{l}\text { Função } \\
\text { de fala }\end{array}$ & Fragmento 3 & $\begin{array}{l}\text { Processo } \\
\text { cognitivo }\end{array}$ & Agente \\
\hline 149 & Inf & $\begin{array}{c}\text { No Caribe eles tiram muita água, no Caribe não, no } \\
\text { Iraque. Oriente Médio. }\end{array}$ & PCE & A3 \\
\hline 150 & Cit-C & Também, lá é tudo deserto, tem que tirar muita água. & PCE & $\mathrm{A} 2$ \\
\hline 151 & Inf & Vinte bilhões de litros de água. & PCE & A3 \\
\hline 152 & Inf & Por dia. Caramba! & PCR & A2 \\
\hline 153 & Cit-C & $\begin{array}{l}\text { É bom tirar mesmo porque em vinte anos a água vai } \\
\text { entrar em crise igual ao petróleo de } 1973 \text {. }\end{array}$ & PCE & $\mathrm{A} 2$ \\
\hline 154 & Ava & É muita coisa. & PCE & A3 \\
\hline 155 & Cit-C & $\begin{array}{l}\text { É muita pensando em número, porque se pensar em } \\
\text { população. }\end{array}$ & PCE & A2 \\
\hline
\end{tabular}

No Quadro 7 apresentamos a frequência expressa em porcentagem com que cada função de fala foi utilizada pelos 5 grupos de base, na primeira e segunda atividade. 
Quadro 7 - Distribuição das funções de fala para cada grupo de base participante da primeira e da segunda atividade.

\begin{tabular}{|c|c|c|c|c|c|c|c|c|c|c|c|}
\hline & \multicolumn{2}{|c|}{$\begin{array}{c}\text { Grupo } 1 \\
(\%)\end{array}$} & \multicolumn{2}{|c|}{$\begin{array}{c}\text { Grupo } 2 \\
(\%)\end{array}$} & \multicolumn{2}{|c|}{$\begin{array}{c}\text { Grupo } 3 \\
(\%)\end{array}$} & \multicolumn{2}{|c|}{$\begin{array}{c}\text { Grupo } 4 \\
(\%)\end{array}$} & \multicolumn{2}{|c|}{$\begin{array}{c}\text { Grupo } 5 \\
(\%)\end{array}$} \\
\hline & & AT1 & AT2 & AT1 & AT2 & AT1 & AT2 & AT1 & AT2 & AT1 & AT2 \\
\hline \multirow{6}{*}{$\frac{\overrightarrow{8}}{0}$} & Int & 26,0 & 26,2 & 20,2 & 28,5 & 29,3 & 25,3 & 24,5 & 24,0 & 29,8 & 27,5 \\
\hline & Res & 17,8 & 16,8 & 19,0 & 19,0 & 22,3 & 17,5 & 19,1 & 19,8 & 20,5 & 21,5 \\
\hline & C-Res & 6,9 & 12,3 & 13,5 & 10,1 & 7,5 & 13,7 & 7,2 & 8,5 & 4,3 & 8,3 \\
\hline & Inf & 7,6 & 8,4 & 11,6 & 7,1 & 12,9 & 6,5 & 13,6 & 14,0 & 11,7 & 7,8 \\
\hline & LVA & 2,7 & 1,3 & 1,7 & 1,8 & 3,1 & 0,3 & 1,9 & 0,0 & 1,0 & 2,0 \\
\hline & $\Sigma$ & 61,0 & 65,0 & 66,0 & 66,5 & 75,1 & 63,3 & 66,3 & 66,3 & 67,3 & 67,1 \\
\hline \multirow{6}{*}{ 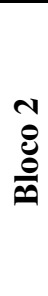 } & Org-A & 9,9 & 10,4 & 8,9 & 6,8 & 6,3 & 7,2 & 7,0 & 10,5 & 8,8 & 10,7 \\
\hline & Exp & 2,4 & 0,3 & 1,2 & 3,0 & 2,1 & 0 & 0,9 & 1,7 & 1,0 & 0 \\
\hline & Jul & 6,2 & 6,5 & 8,4 & 4,7 & 4,0 & 6,5 & 5,6 & 7,5 & 6,6 & 5,4 \\
\hline & Ava & 3,8 & 2,3 & 4,7 & 5,0 & 3,3 & 4,8 & 6,9 & 2,8 & 4,5 & 1,0 \\
\hline & Afe & 0,1 & 0,3 & 0,4 & 0,0 & 0,3 & 0,0 & 0,8 & 2,5 & 1,6 & 0,0 \\
\hline & $\Sigma$ & 22,4 & 19,8 & 23,6 & 19,5 & 16,0 & 18,5 & 21,2 & 25,0 & 22,5 & 17,1 \\
\hline \multirow{4}{*}{$\begin{array}{l}m \\
\dot{\delta} \\
0\end{array}$} & Cit-C & 7,6 & 7,4 & 4,9 & 5,6 & 3,7 & 8,2 & 4,1 & 2,5 & 4,7 & 5,4 \\
\hline & Org-I & 4,2 & 4,9 & 2,3 & 3,6 & 1,9 & 4,8 & 3,2 & 3,5 & 2,6 & 6,4 \\
\hline & Res-C & 2,3 & 0,6 & 1,2 & 2,1 & 2,1 & 1,4 & 1,5 & 1,0 & 0,7 & 2,0 \\
\hline & $\Sigma$ & 14,1 & 12,9 & 8,4 & 11,3 & 7,7 & 14,4 & 8,8 & 7,0 & 8,0 & 13,8 \\
\hline & Inc & 2,5 & 2,3 & 2,0 & 2,7 & 1,2 & 3,8 & 3,7 & 1,7 & 2,2 & 2,0 \\
\hline & Total & $100 \%$ & $100 \%$ & $100 \%$ & $100 \%$ & $100 \%$ & $100 \%$ & $100 \%$ & $100 \%$ & $100 \%$ & $100 \%$ \\
\hline
\end{tabular}

Int= interrogação; Res= resposta; $\mathrm{C}$-Res $=$ complemento de resposta; Inf $=$ informação; LVA= leitura em voz alta; Org-A= organização de ação; Exp= experencial; Jul= julgamento; Ava= avaliação; Afe= afetiva; Cit-C = citação crítica; Org-I= organização de idéia; Res-C= resposta crítica e Inc =Inclassificável; AT1 e $\mathrm{AT} 2=$ primeira e segunda atividade dos grupos de base, respectivamente.

Com relação às funções de fala que compõem o primeiro bloco, a somatória das mesmas não é inferior a $60 \%$ em nenhum dos grupos. Este resultado indica que os alunos participaram efetivamente da atividade, compartilharam informações, assim como formularam e responderam questionamentos. De fato, o número de funções de resposta somado ao de funções de complemento de resposta é muito próximo ao número de interrogações no Grupo 1 (AT1) e no Grupo 5 (AT1) e superior nos demais casos, o que demonstra que algumas perguntas encontraram mais do que uma resposta.

Com relação às funções de fala que compõem o segundo bloco, a somatória das mesmas varia entre $16 \%$ e $25 \%$ nos grupos. A mais usada em todos eles foi a organização de ação, seguida pelas funções, julgamento e avaliação. As menos usadas foram as funções experiencial e afetiva, provavelmente, devido ao fato dos alunos serem ingressantes e não terem ainda estreitado seus laços de amizade, o que favoreceria o relato de experiências pessoais e expressão de sentimentos. Em contraponto, o uso mais efetivo das funções de organização de ação, de julgamento e de avaliação aponta para a busca da organização da atividade e mostra que os alunos não se omitiram frente ao 
trabalho dos colegas, avaliaram e julgaram as respostas dadas por eles. Assim, foi possível para os membros dos grupos o desenvolvimento de habilidades sociais.

Com relação às funções de fala que compõem o terceiro bloco, a somatória das mesmas varia entre $7 \%$ e 14,4\% nos grupos. A baixa porcentagem de tais funções não é surpreendente, uma vez que exigem um grau elevado de elaboração por parte dos alunos para que a sua expressão se concretize. Mais importante do que o resultado em valor absoluto de uso das mesmas é a constatação de que os alunos foram capazes de elaborar respostas críticas. De fato, por vezes, o grau de organização e as funções direcionadas à finalização da atividade, levaram à vivência de momentos argumentativos, pautados na especulação de resultados e na formulação de hipótese, que conduzem ao desenvolvimento de habilidades valorizadas pela comunidade de educadores em ciência. Distribuição das funções de fala nos grupos de especialistas

A mesma sistemática de análise adotada para a tessitura de considerações sobre as funções de fala nos grupos de base foi seguida para os grupos de especialistas. Assim, o Quadro 8 ilustra a frequência expressa em porcentagem com que cada função de fala foi utilizada pelos 5 grupos de especialistas.

Quadro 8 - Distribuição das funções de fala para cada grupo de especialistas.

\begin{tabular}{|c|c|c|c|c|c|c|}
\hline & & $\begin{array}{c}\text { Artigo de } \\
\text { Educação } \\
(\%) \\
\end{array}$ & $\begin{array}{c}\text { Artigo de } \\
\text { Divulgação } \\
(\%)\end{array}$ & $\begin{array}{c}\text { Artigo de } \\
\text { Revisão } \\
(\%)\end{array}$ & $\begin{array}{c}\text { Artigo } \\
\text { Original } \\
(\%)\end{array}$ & $\begin{array}{c}\text { Tese ou } \\
\text { Dissertação } \\
(\%)\end{array}$ \\
\hline \multirow{6}{*}{$\frac{\ddot{8}}{\stackrel{0}{0}}$} & Int & 27,6 & 24,7 & 27,7 & 23,5 & 10,9 \\
\hline & Res & 25,4 & 25,4 & 22,9 & 19,2 & 19,8 \\
\hline & C-Res & 8,8 & 2,3 & 7,6 & 7,3 & 8,9 \\
\hline & Inf & 5,0 & 6,8 & 8,4 & 9,2 & 7,4 \\
\hline & LVA & 5,9 & 6,1 & 3,2 & 2,6 & 5,9 \\
\hline & $\Sigma$ & 72,7 & 65,3 & 69,8 & 61,8 & 52,9 \\
\hline \multirow{6}{*}{ 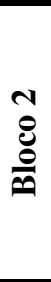 } & Org-A & 6,4 & 5,5 & 5,6 & 5,2 & 12,9 \\
\hline & $\operatorname{Exp}$ & 0,7 & 2,1 & 0,4 & 1,9 & 1,0 \\
\hline & Jul & 5,7 & 6,8 & 4,8 & 8,4 & 6,9 \\
\hline & Ava & 4,6 & 3,6 & 2,4 & 3,8 & 6,7 \\
\hline & Afe & 0,0 & 1,1 & 0,0 & 0,5 & 1,2 \\
\hline & $\Sigma$ & 17,4 & 19,1 & 13,2 & 19,8 & 28,7 \\
\hline \multirow{4}{*}{$\stackrel{m}{\mathscr{U}}$} & C-Cri & 3,9 & 6,6 & 6,4 & 6,8 & 6,7 \\
\hline & Org-I & 3,5 & 5,5 & 2,8 & 7,0 & 5,4 \\
\hline & Res-C & 2,0 & 2,8 & 6,8 & 2,8 & 5,2 \\
\hline & $\Sigma$ & 9,4 & 14,9 & 16,0 & 16,6 & 17,3 \\
\hline & Inc & 0,5 & 0,7 & 1,0 & 1,8 & 1,1 \\
\hline & Total & $100 \%$ & $100 \%$ & $100 \%$ & $100 \%$ & $100 \%$ \\
\hline
\end{tabular}

Int= interrogação; Res= resposta; C-Res= complemento de resposta; Inf $=$ informação; LVA= leitura em voz alta; Org-A= organização de ação; Exp= experencial; Jul= julgamento; Ava= avaliação; Afe= afetiva; Cit-C= citação crítica; Org-I= organização de ideia; Res-C= resposta crítica e Inc =Inclassificável. 
A análise dos dados expostos no Quadro 8 evidencia que os grupos fizeram uso das funções de fala de forma muito semelhante entre si e também com relação aos grupos de base. Todos usaram de forma intensa as funções de fala que compõem o primeiro bloco, de modo que, com exceção do grupo de especialistas em tese e dissertação, para os demais, a somatória das mesmas, não é inferior a 60\%. Também de forma similar aos grupos de base, o número de funções de fala do tipo resposta e do complemento de resposta somados apresentaram valor maior do que as funções do tipo interrogação em todos os grupos de especialistas. Este resultado indica que, em ambos os tipos de grupos, os alunos participaram efetivamente da atividade, compartilhando informações, formulando e respondendo questionamentos. É digno de nota, o fato de a função leitura em voz alta ter porcentual mais alto nos grupos de especialista, com a sua somatória variando na faixa entre 2,6\% e 6,1\%, enquanto nos grupos de base, a variação oscilou na faixa de zero a 2,7\%. Tal intensificação no uso dessa função deve-se ao fato de todos os alunos terem lido nos grupos de especialistas as respostas que trouxeram elaboradas para cada um dos tipos de documentos científicos, como exigido na atividade extraclasse.

Com relação ao uso das funções do segundo bloco, verifica-se a mesma tendência de semelhança entre os grupos de base e os grupos de especialistas. A função mais usada em todos eles foi a organização de ação, seguida pelas funções julgamento e avaliação e as menos usadas foram as funções experiencial e afetiva. Os resultados levam a crer que, em ambos os tipos de grupos, os alunos buscaram organizar a atividade e se preocuparam em avaliar e julgar os posicionamentos assumidos pelos colegas, no entanto, não fizeram de forma considerável relatos de experiências pessoais e não expressaram sentimentos.

Com relação ao uso das funções do terceiro bloco, verificou-se tendência similar para as funções, citação crítica e organização de ideia. Em contraponto, para a função resposta crítica verificou-se um porcentual mais alto nos grupos de especialista, com a sua somatória variável entre $2,0 \%$ e $6,8 \%$, enquanto nos grupos de base, a variação oscilou na faixa de $0,6 \%$ e $2,3 \%$. Tal intensificação pode ser decorrente do fato de os alunos que compuseram os grupos de especialistas já terem estudado individualmente o conteúdo abordado na discussão, a partir do oferecimento de respostas às questões da atividade extraclasse. Ou seja, enquanto participantes dos grupos de especialistas, os alunos estavam munidos de conhecimentos que os subsidiaram na elaboração de uma 
quantidade maior de respostas críticas aos questionamentos dos colegas, do que enquanto participantes dos grupos de base.

Segunda dimensão: processamento cognitivo

Processamento cognitivo nos grupos de base: primeira e segunda atividade

A Figura 4 apresenta a porcentagem de uso dos 3 tipos de processamentos cognitivos pelos grupos de base na primeira e segunda atividade. Os grupos de base usaram os processamentos cognitivos seguindo a mesma tendência nas duas atividades, sendo que o processamento cognitivo rotineiro usado prioritariamente, seguido do processamento cognitivo off-task e, por último, o processamento cognitivo exploratório. Essa ordem corrobora os resultados alcançados na primeira dimensão analisada, de modo que o alto percentual verificado para o processamento cognitivo rotineiro (superior a $60 \%$ em todos os grupos, tendo valor máximo de $91 \%$ no Grupo 4, na primeira atividade) confirma que os alunos trabalharam de forma comprometida, embora tenham dirigido seus esforços, principalmente, à realização de atividades que exigiram apenas a manipulação, organização e execução, sem análise reflexiva.

a)
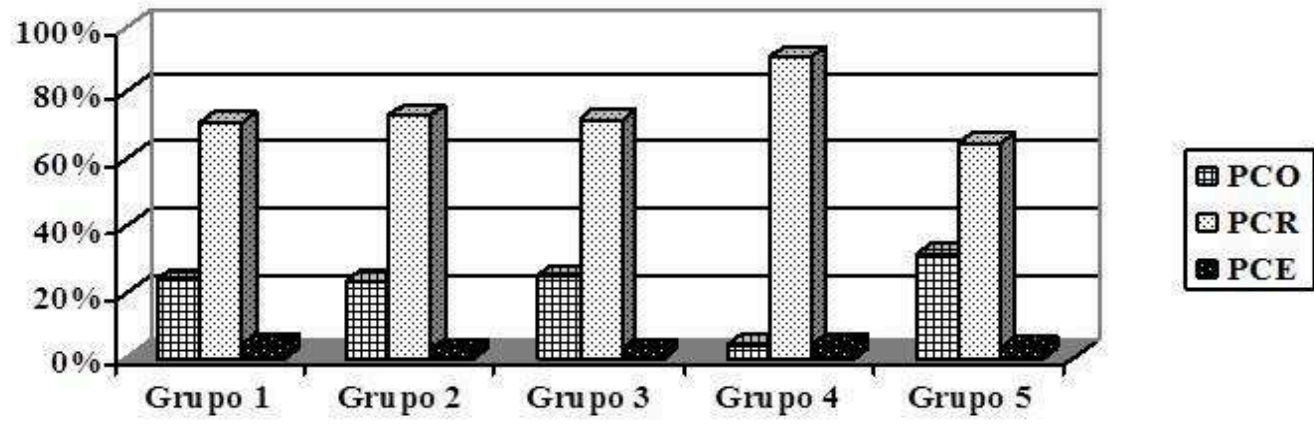

b)

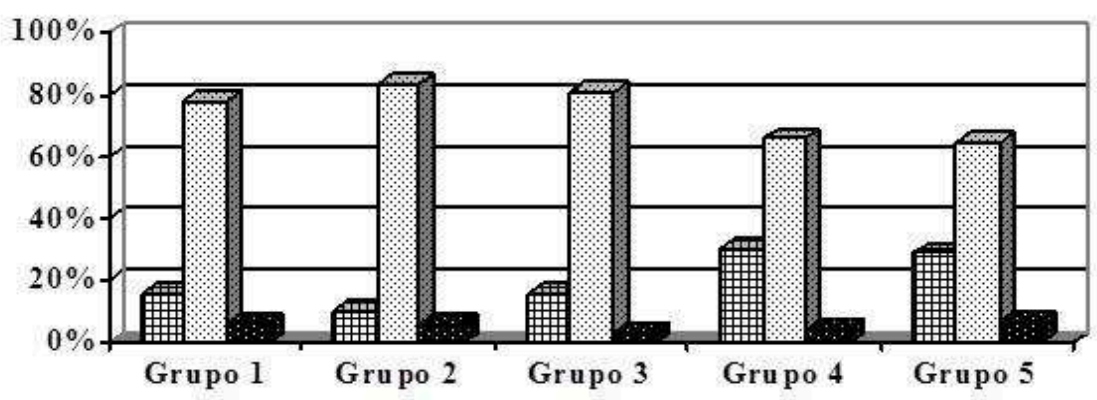

Figura 4 - Porcentagem de uso dos processamentos cognitivos durante a resolução da primeira (a) e segunda (b) atividade dos grupos de base. $\mathrm{PCO}=$ processamento cognitivo off-task; $\mathrm{PCR}=$ processamento cognitivo rotineiro; $\mathrm{PCE}=$ processamento cognitivo exploratório.

A importância do processamento do tipo rotineiro é clara e, embora o seu uso majoritário possa representar o empenho dos alunos, não oferece indícios sobre a realização de um trabalho amistoso e descontraído. Nessa perspectiva, é relevante a 
análise do processamento do tipo off-task, verificado em todos os grupos e indicativo de que os alunos desenvolveram a atividade de forma descontraída, intercalando a execução das tarefas com momentos sem tensões. $\mathrm{O}$ uso do processamento cognitivo off-task, mostrou-se variável entre os grupos nas duas atividades: como tendência, verifica-se que a maioria dos grupos, com exceção do Grupo 4, diminuiu o seu grau de descontração da primeira para a segunda atividade. Este fato está relacionado, provavelmente, com o caráter finalizador da segunda atividade. Cabe destacar, que o número excessivo de processamento cognitivo off-task, pode prejudicar a resolução das tarefas e qualidade das respostas, quando isso ocorre, temos um exemplo de interdependência negativa, de forma que um ou mais alunos não conseguem desenvolver o trabalho em sintonia com os demais, o que prejudica o trabalho em grupo.

O uso do processamento cognitivo exploratório ocorreu de forma muito parecida em todos os grupos, na primeira atividade, com valor aproximado de 4,0\%. Na segunda atividade, os valores variaram de 4,0\% a 6,6\%. O aumento no uso desse tipo de processamento evidencia uma evolução no decorrer da atividade, sugerindo que os alunos realizaram um trabalho mais ativo e buscaram respostas mais elaboradas.

Processamento cognitivo nos grupos de especialistas

Os processamentos cognitivos usados pelos grupos de especialistas seguiram, de maneira geral, tendências semelhantes às verificadas nos grupos de base na primeira e segunda atividade, conforme ilustra a Figura 5.

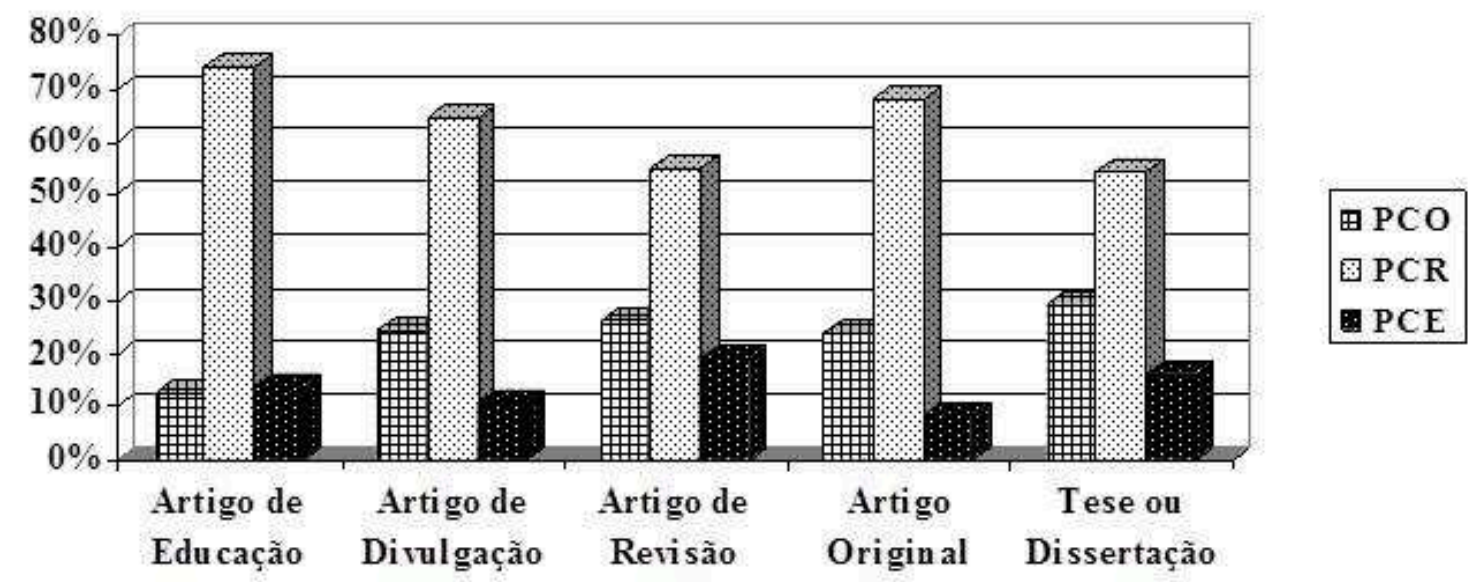

Figura 5 - Porcentagem de uso dos processamentos cognitivos durante a resolução da atividade dos grupos de especialistas.

O uso de processamento cognitivo rotineiro, mais uma vez foi prioritário em todos os grupos, o que mostra que os alunos mantiveram-se focados na resolução da 
atividade. Ou seja, mesmo não estando em seus grupos de base, os alunos não deixaram que o trabalho no grupo de especialistas tomasse um rumo de desorganização. Com relação ao uso do processamento cognitivo off-task, este se manteve em nível semelhante praticamente em todos os grupos (em torno de $20 \%$ ), assim como havia sido observado em grande parte dos grupos de base.

Com relação ao uso do processamento cognitivo exploratório, sua frequência mostrou-se bem diferente quando comparada à observada nos grupos de base. De fato, a Figura 5 mostra que o uso do processamento cognitivo exploratório teve seu mínimo de $8,2 \%$ no grupo especialista em artigo original e máximo de $19,1 \%$ no grupo especialista em artigo de revisão. Assim, o grupo de especialista responsável pelo uso mínimo de processamentos exploratórios empregou, em valores percentuais, o dobro do valor dos grupos de base, que o fizeram em torno de $4 \%$.

Provavelmente, essa diferença esteja diretamente relacionada à estrutura da atividade, o grupo de especialista tem exatamente o propósito de fazer com que os alunos se encontrem em situação de igualdade para discutir uma melhor resposta. $\mathrm{O}$ uso mais frequente do processamento do tipo exploratório sugere que o objetivo da atividade foi contemplado, de forma que os alunos tiveram a chance de enfrentar conflitos cognitivos, geraram um esforço para compreender e resolver problemas.

Terceira dimensão: processamento social

Processamento social nos grupos de base: primeira e segunda atividade

Com o uso dos mapas analíticos construídos para cada grupo de base, identificamos as interações dominantes ocorridas no decorrer da resolução da primeira e da segunda atividade. Na Figura 6 são expostos os 4 tipos de interações sociais, assim como os valores em porcentagem referentes à frequência de seu uso. 
a)

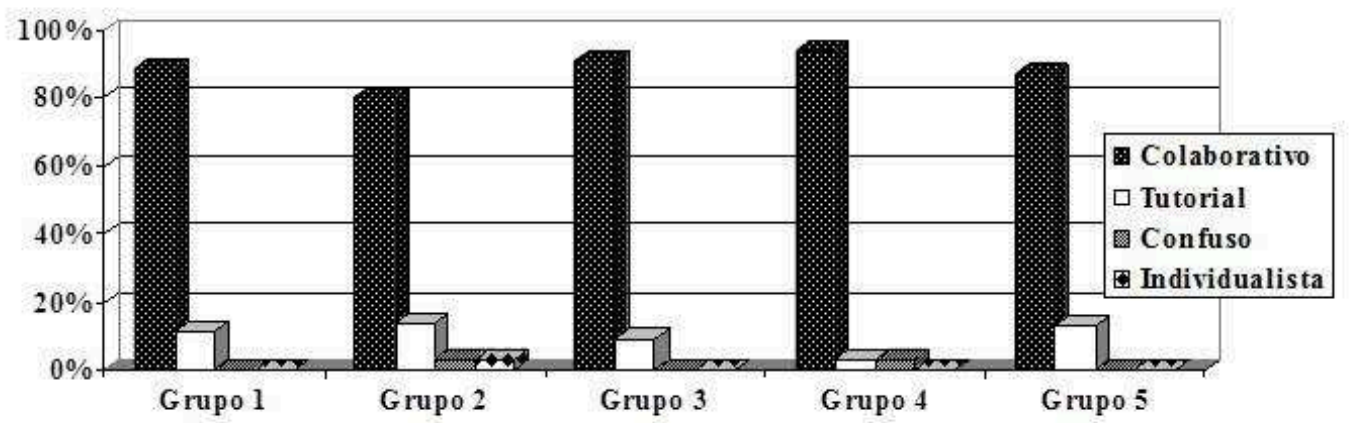

b)

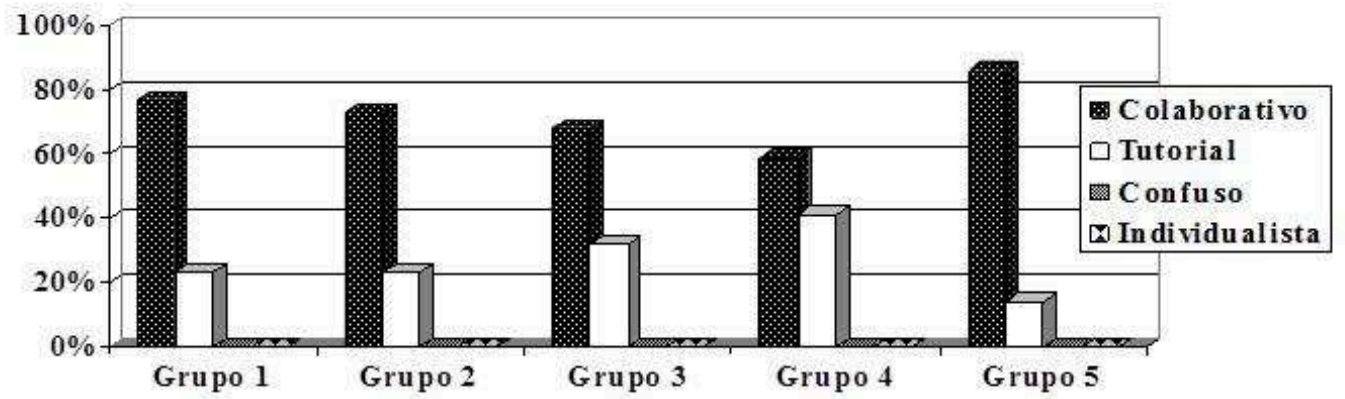

Figura 6 - Porcentagem de uso dos processamentos sociais durante a resolução da primeira (a) e da segunda (b) atividade dos grupos de base.

A primeira atividade de grupo de base apresentou predominantemente interação social do tipo colaborativa, com porcentagem em torno de $80 \%$ em todos os grupos, sendo seguida pela interação do tipo tutorial. O elevado grau de cooperação, evidenciado pelo predomínio do processamento social do tipo colaborativo ou tutorial, demonstra que a atividade conseguiu gerar nos alunos uma interdependência positiva, tornando-os parte de um conjunto, considerando o seu rendimento e também o rendimento dos seus companheiros.

Na primeira atividade, verifica-se a ocorrência de interações do tipo confusa por duas vezes e individualista uma vez. A interação do tipo confusa ocorreu apenas uma vez em 2 dos grupos (Grupo 2 e Grupo 4), no começo das suas atividades, em momentos em que os alunos não conseguiram definir uma estratégia para dar andamento aos seus trabalhos. Entretanto, este tipo de interação, seguido por interações tutoriais, levaram ambos os grupos a interagir de forma colaborativa. Com relação à interação do tipo individualista, a mesma foi pontual (Grupo 2) e não interferiu no bom andamento da atividade.

Com relação à segunda atividade, houve um avanço nas interações sociais desenvolvidas pelos alunos, uma vez que 100\% delas foram do tipo cooperativa, 
divididas entre processamento social colaborativo e tutorial, indicando uma evolução natural, advinda, provavelmente, da estratégia jigsaw.

Nessa perspectiva, evidencia-se que a atividade, constituída em um período longo, trouxe benefícios para os alunos, que frente à repetição e reflexão sobre questões presentes na tarefa, tiveram a chance de evoluir em seu trabalho, individualmente e coletivamente, tornando-o mais cooperativo e eficiente.

Processamento social nos grupos de base: grupo de especialistas

As interações sociais predominantes nos grupos de especialistas, assim como nos grupos de base, foram do tipo colaborativa, conforme ilustrado na Figura 7.

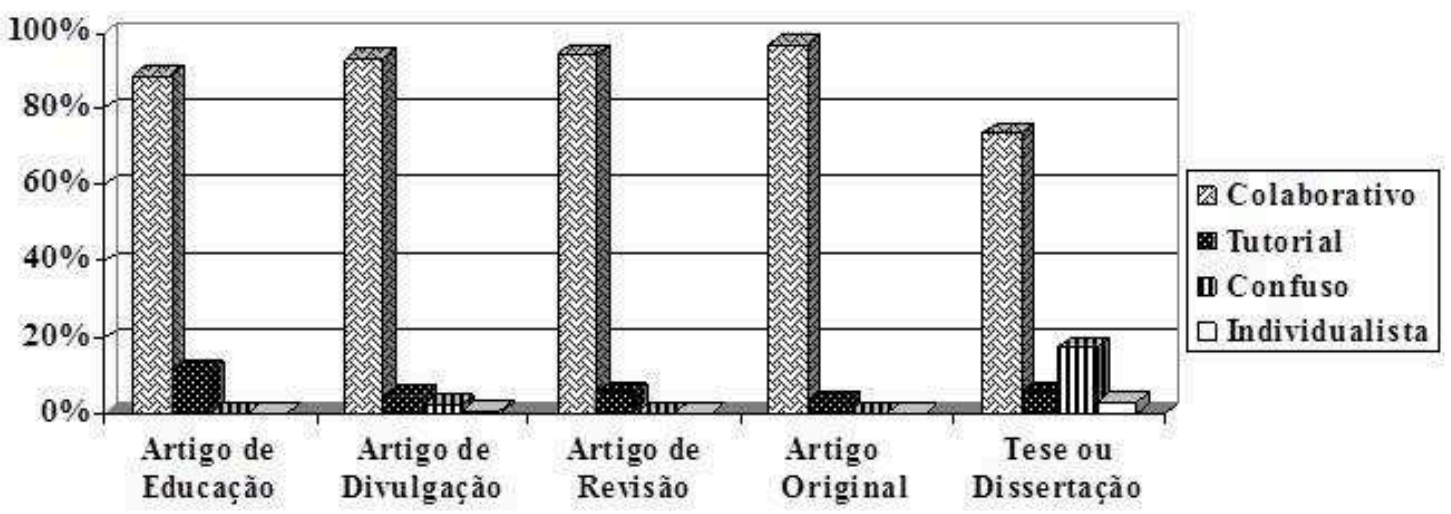

Figura 7 - Porcentagem de uso dos processamentos sociais durante a resolução da atividade dos grupos de especialistas.

Em todos os grupos as interações do tipo colaborativa foram superiores a 70\%, indicando o estabelecimento de uma interação na qual os alunos facilitam, com seus esforços, a aprendizagem dos demais. Essas interações sugerem uma atividade rica em possibilidades de crescimento social para os alunos. Entretanto, no grupo de especialista em tese ou dissertação ocorreram interações que foram marcadas por atitudes não colaborativas, sendo $17 \%$ das interações do tipo confusa e $3 \%$ do tipo individualista. Estas refletem um comportamento individualista dos alunos e, por vezes, competitivo. Dois membros do grupo desviaram o foco da atividade o que passou a ser, em alguns momentos, motivo de conflito, gerando também um percentual mais elevado que o dos demais grupos, no que diz respeito ao processamento cognitivo off-task (em torno de $30 \%$ ), conforme ilustra a Figura 5.

\section{Avaliação dos alunos frente à atividade proposta}

Com o término do jigsaw, os alunos responderam a um questionário sobre a atividade cooperativa. Este, respondido por 60 alunos, pautou-se no trabalho de Eilks (2005) e continha 15 afirmações: 
1. Eu pude trabalhar com mais independência no formato de aula jigsaw do que faço normalmente nas aulas expositivas;

2. Eu teria gostado mais se o professor tivesse nos ajudado mais diretamente e corrigido o nosso trabalho após cada uma das etapas do jigsaw;

3. Eu trabalhei com mais intensidade no formato de aula jigsaw do que costumo trabalhar durante as aulas expositivas/expositivas dialogadas;

4. Eu prefiro quando o professor discute tópicos com a classe toda (aula expositiva dialogada) do que quando nós temos que trabalhar em pequenos grupos;

5. Eu acredito que aprendi muito sobre o conteúdo "Algumas formas de divulgação científica" trabalhando no formato de aula jigsaw;

6. Eu não gostei de trabalhar no formato de aula jigsaw porque meu trabalho ficou muito dependente do desempenho dos meus colegas;

7. Eu acho que o formato de aula jigsaw é confuso e desestruturado;

8. Eu gostei de trabalhar no formato de aula jigsaw porque pude trabalhar junto com outros colegas;

9. Foi difícil organizar sozinhos o nosso trabalho no formato de aula jigsaw;

10. O uso de diferentes métodos de ensino (como o formato de aula jigsaw) torna nossas aulas mais divertidas e menos cansativas;

11. Acredito que a distribuição de papéis entre os participantes dos grupos de base facilitou a realização das atividades solicitadas pelo professor;

12. Acredito que a distribuição de papéis entre os participantes dos grupos de base facilitou a organização do trabalho do grupo;

13. Ter um papel específico a desempenhar no grupo me ajudou no desenvolvimento de novas habilidades ou no aperfeiçoamento de habilidades que eu já possuía;

14. Considero que o processamento grupal, realizado no final dos trabalhos dos grupos de base, é importante para o bom andamento das atividades no grupo;

15. Eu gostaria de participar novamente de aulas no formato jigsaw na disciplina de comunicação científica.

A frequência das respostas, expressa em escala Likert de 5 pontos (Concordo Fortemente (CF), Concordo (C), Indeciso (I), Discordo (D), Discordo Fortemente (DF)), foi quantificada e analisada. Na Figura 8 é apresentada a quantificação da frequência das respostas, em porcentagem. O eixo x corresponde à numeração das afirmações 
citadas anteriormente e o eixo y corresponde à frequência de respostas dadas pelos alunos em escala Likert.

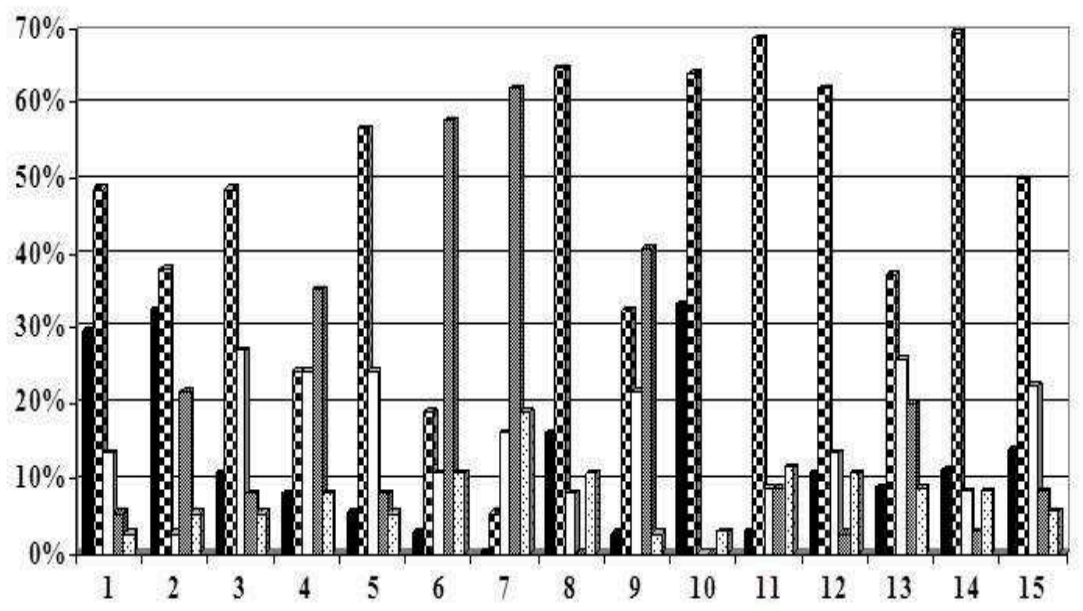

Concordo Fortem ente Concordo

$\square$ Indeciso

Discordo

Discordo Fortem ente

\section{Afirmações}

Figura 8 - Questionário de avaliação da atividade proposta, na qual $\mathrm{CF}=\mathrm{Concordo}$ Fortemente, $\mathrm{C}=$ Concordo, I= Indeciso, D= Discordo e DF= Discordo Fortemente.

Para que a discussão a respeito da avaliação dos graduandos sobre a proposta pudesse ser feita de forma mais clara, inicialmente agrupamos as afirmações contidas no questionário em 3 categorias. As respostas dadas para as afirmações 1, 3, 6, 8 e 15, relacionam-se à opinião dos alunos com relação à sua conduta durante a realização da estratégia e à sua satisfação com relação à atividade realizada.

Nas afirmações 1 e 3, os alunos opinaram sobre a independência e intensidade com que conduziram as tarefas pertencentes à atividade realizada. Os resultados foram positivos uma vez que grande parte deles afirma ter trabalhado com maior independência (78,4\%, somatório das respostas CF e C) e intensidade $(59,4 \%$, somatório das respostas $\mathrm{CF}$ e C) durante a realização da atividade.

Com relação às impressões dos alunos sobre a dependência do trabalho dos demais colegas para o sucesso da tarefa realizada (afirmações 6 e 8), é possível verificar que os resultados foram bastante favoráveis à proposta, uma vez que a discordância em relação à afirmação 6 foi elevada: $68,6 \%$ de discordância (somatório das respostas D e DF). De forma complementar, a maioria dos alunos concordou haver gostado de trabalhar no formato de aula jigsaw porque era possível trabalhar junto com os outros colegas (afirmação 8): 81,1\% de concordância (somatório das respostas C e CF).

A satisfação dos alunos frente às atividades realizadas foi considerável, uma vez que a concordância em relação à afirmação 15 , a qual se referia ao desejo de nova 
participação em aulas no formato jigsaw, superou a metade dos alunos: 63,9\% de concordância (somatório das respostas $\mathrm{C}$ e $\mathrm{CF}$ ).

As afirmações 2, 4, 5, 7, 9 e 10 dizem respeito à opinião dos alunos sobre a realização das atividades no formato jigsaw (questões 7 e 10) e às suas contribuições para o aprendizado dos conteúdos estudados (questão 5), assim como às suas percepções com relação à conduta do professor $(2,4$ e 9).

As respostas dadas à afirmação 10 mostram que 97,2\% dos alunos concordaram (somatório das respostas $\mathrm{C}$ e $\mathrm{CF}$ ) que métodos como o jigsaw tornam as aulas mais divertidas. As respostas dadas à afirmação 7 evidenciam que os alunos, em sua maioria, reconheceram a atividade como organizada, o que é relevante, já que um dos maiores obstáculos ao trabalho em grupo reside, justamente, na dificuldade da organização das tarefas. De fato, verificamos que $81,1 \%$ dos alunos discordaram (somatório das respostas $\mathrm{D}$ e DF) da afirmação que diz ser o formato de aula jigsaw confuso e desestruturado. Esse resultado positivo se deve, provavelmente, aos seguintes fatores: a organização, imposta pela própria estrutura da atividade cooperativa, e à forma com que o docente conduziu a disciplina.

No que diz respeito ao favorecimento da compreensão de conceitos (afirmação 5), a grande maioria dos alunos concordou com tal afirmação. Assim, a natureza cooperativa do formato jigsaw não prejudicou o aprendizado dos conteúdos ministrados na disciplina.

Três afirmações se relacionavam à condução da aula pelo professor: a primeira, de caráter geral (afirmação 4), solicitava aos alunos que indicassem se preferiam o formato de aula expositiva dialogada ao formato em pequenos grupos; a segunda, de caráter específico (afirmação 2), solicitava que indicassem se teriam gostado mais da atividade no formato adotado, caso o professor os tivesse auxiliado mais diretamente no processo, corrigindo os trabalhos após cada uma das etapas do jigsaw; a terceira, de caráter especifico, também questionava a dificuldade em organizar sozinho o trabalho no formato de aula jigsaw. No que diz respeito à afirmação 4, 32,4\% dos alunos explicitaram sua preferência por aulas expositivas dialogadas (somatório das respostas $\mathrm{CF}$ e C) e 43,3\% por aulas nas quais predominam atividades em grupo (somatório das respostas DF e D), enquanto 24,3\% declararam-se indecisos frente à afirmação.

Tal resultado não é surpreendente, pois pesquisas indicam que do ponto de vista de muitos alunos, ensinar é algo que só os professores podem fazer, sendo mais confortável para eles um estilo de ensino baseado exclusivamente na exposição do 
professor (HAGEN, 2000). O fato de a cooperação entre os pares ainda não estar presente de forma sistemática nos cursos universitários, dificulta o desenvolvimento nos alunos do sentimento da importância dessa cooperação.

No que diz respeito à afirmação 2, a maioria dos alunos, 70,3\%, (somatório das respostas $\mathrm{CF}$ e $\mathrm{C}$ ), indicou que teria gostado mais do jigsaw se tivesse sido ajudado mais diretamente pelo docente, somado a isso as respostas à questão 9, 35,0\% (somatório das respostas $\mathrm{CF}$ e C) dos alunos afirmaram preferir que o professor ajudasse na organização da atividade. Os alunos podem ter se surpreendido com o papel desempenhado pelo professor. Papel esse que na aprendizagem cooperativa ganha novas dimensões: quanto mais bem sucedido for o professor, maior será a transferência de 'poder' para os alunos, assim eles se tornarão mais autônomos, responsáveis e capazes de se organizarem.

As respostas dadas para as afirmações 11, 12, 13 e 14 dizem respeito à opinião dos alunos sobre a realização das atividades no formato jigsaw com funções determinadas pelo docente (afirmações 11, 12 e 13) e às contribuições do processamento grupal para o desenvolvimento da atividade desenvolvida (afirmação 14).

A aceitação das funções propostas pelo docente mostrou-se quase total, o que pode ser visto na afirmação 11 e na afirmação 12, na qual mais de $70 \%$ dos alunos afirmaram (somatório das respostas $\mathrm{C}$ e $\mathrm{CF}$ ) que as funções definidas pelo docente facilitaram a resolução da atividade e contribuíram para a organização da atividade. Além do caráter prático das funções, $45,7 \%$ dos alunos ainda revelaram na afirmação 13, acreditar que as funções ajudaram no desenvolvimento de habilidades. Aliada a isso, temos a constatação da afirmação 14 , na qual $80,6 \%$ dos alunos confirmaram que o processamento grupal ajudou na organização da atividade.

Assim como no trabalho reportado por Eilks (2005), os alunos reagiram positivamente à aplicação da atividade no formato jigsaw. As respostas dadas ao questionário de avaliação mostraram sua satisfação com relação a esse formato de atividade, especialmente devido ao fato de terem trabalhado com mais independência (78,3\% de respostas favoráveis à afirmação 1) e junto com outros colegas $(81,1 \%$ de respostas favoráveis à afirmação 8). Ademais, foi praticamente unânime a concordância dos alunos com relação ao fato de aulas neste formato serem divertidas e pouco cansativas $(97,2 \%$ de respostas favoráveis à afirmação 10$)$. 
É também digna de nota, a importância creditada pelos alunos à atribuição de papéis entre os participantes do grupo de base $(71,4 \%$ de respostas favoráveis a questão $11 ; 73,0 \%$ favoráveis a questão 12$)$ e ao processamento grupal $(80,6 \%$ das respostas favoráveis a questão 14). Tais resultados corroboram as recomendações expressas por Johnson et al. (1999) no sentido da promoção da interdependência positiva no grupo e da realização do processamento grupal.

Opiniões negativas frente às afirmações presentes no questionário foram raras. No entanto, como os estudantes não eram experientes no desenvolvimento de atividades no formato jigsaw, acreditamos que, possivelmente, tais opiniões seriam amenizadas caso eles tivessem outras oportunidades de familiarização com o método.

\section{Considerações finais}

No contexto nacional são ainda escassas as pesquisas sobre as formas de organização e a efetividade das atividades didáticas baseadas nos princípios da aprendizagem cooperativa, especialmente no ensino de química. Neste trabalho, colocamos em funcionamento uma atividade didática pautada nos preceitos da aprendizagem cooperativa no formato jigsaw

O acompanhamento da aplicação da atividade nos permitiu investigar a dinâmica das interações estabelecidas entre os alunos, dentro dos seus respectivos grupos, a partir da análise das seguintes dimensões: funções da fala, processamento cognitivo e processamento social. De forma complementar, analisamos as percepções dos alunos com relação à aplicação da atividade, fazendo uso de questionário composto por 15 afirmações.

Com relação às funções de fala empregadas na primeira atividade nos grupos de base, os alunos usaram de forma predominante as funções do tipo interrogação (Int), resposta (Res), complemento de resposta (C-Res) e informação (Inf). Essa preferência indica um forte comprometimento por parte dos alunos em realizar a tarefa proposta de forma eficiente. Aliada ao uso de tais funções, a ocorrência de processamento cognitivo rotineiro (PCR) foi elevada, o que corrobora o referido comprometimento. Já com relação às interações estabelecidas nos grupos de base, estas ocorreram de forma cooperativa, sendo conduzidas predominantemente por processamentos sociais do tipo colaborativo e tutorial, com poucos episódios definidos por processamentos sociais do tipo confusos e individualistas. 
Com relação às funções de fala empregadas na segunda atividade dos grupos de base, a mesma tendência da primeira atividade foi observada, sendo as funções do tipo interrogação (Int), resposta (Res), complemento de resposta (C-Res) e informação (Inf) as mais usadas. Entretanto, é digno de nota o aumento do uso das funções resposta crítica (Res-C), citação critica (Cit-C) e organização de ideia (Org-I), indicando uma evolução com relação à atividade realizada no primeiro grupo de base. Reforça a constatação acima, a observação do aumento também no uso do processamento cognitivo exploratório (PCE), evidenciando uma evolução no decorrer da atividade e sugerindo que os alunos realizaram um trabalho mais ativo e buscaram respostas mais elaboradas.

Cabe ressaltar ainda que na segunda atividade, os alunos possuíam conhecimentos bastante pareados com relação ao conteúdo ministrado na disciplina, tendo cada um que contribuir com parte essencial para o cumprimento da tarefa solicitada. Esse aspecto tornou a participação de cada um deles mais importante e efetiva, justificando, pelo menos parcialmente, a evolução observada. Já com relação aos processamentos sociais realizados na segunda atividade, também observamos que houve um avanço nas interações sociais desenvolvidas pelos alunos, uma vez que $100 \%$ delas foram cooperativas, divididas entre processamento social colaborativo e tutorial.

Diante do exposto, concluímos que as atividades nos grupos de base proporcionaram aos alunos um ambiente cooperativo, no qual participaram de forma consideravelmente igualitária, desenvolvendo suas habilidades acadêmicas, atendendo, portanto, a grande parte das expectativas da aprendizagem cooperativa.

Nos grupos de especialistas, destacamos o uso das funções de fala do tipo organização de ação (Org-A), experiencial (Exp), julgamento (Jul), avaliação (Ava) e afetiva (Afe). Mesmo o uso de tais funções não sendo prioritário, mostrou-se significativo, pois refletiu a intenção dos alunos em coordenar o trabalho do grupo e em contribuir com sugestões concordantes ou discordantes, de forma a avaliar o trabalho dos seus pares. Esses aspectos indicam uma forte interação nos grupos de especialistas, que passaram por vários episódios especulativos. Destacamos ainda que o uso das funções de fala, organização de ideia (Org-I), citação crítica (Cit-C) e resposta crítica (Res-C) foi significativo, demonstrando que existiram alguns momentos de conflitos cognitivos durante a atividade, levando os alunos à busca de respostas bem elaboradas. Tal fato é confirmado pelo elevado uso do processamento cognitivo do tipo exploratório (PCE) que teve seu mínimo de 8,2\% no grupo especialista em Artigo Original e máximo 
de 19,1\% no grupo especialista em Artigo de Revisão. Assim, o grupo de especialista responsável pelo uso mínimo de processamentos exploratórios usou, em valores percentuais, o dobro do valor dos grupos de base, que o fizeram em torno de $4 \%$. Nos grupos de especialistas foi também mantida uma postura cooperativa, verificando-se processamento social colaborativo com valores superiores a $70 \%$.

Diante do exposto, acreditamos que a atividade de especialista também proporcionou aos alunos um ambiente cooperativo, no qual tiveram a chance de enfrentar conflitos cognitivos, que geram um esforço para compreender e resolver problemas.

Assim, podemos inferir, primeiramente, que a aprendizagem cooperativa pode ser adaptada com sucesso ao ensino superior de química; segundo, o seu uso acarreta benefícios acadêmicos e sociais para os alunos, que em busca de melhores respostas às questões colocadas pelo professor, interagem de forma intensa. Por fim, se coadunam com as constatações apresentadas acima, as impressões dos alunos frente à atividade. A grande maioria trabalhou de forma mais independente e apreciou a realização das tarefas em cooperação com outros colegas. Ademais, a atividade mostrou-se divertida e pouco cansativa, confirmando o fator motivacional vinculado às estratégias cooperativas.

Cabe esclarecer aos que pretendem lançar mão de estratégias cooperativas em ambientes de ensino, que é importante estar consciente que a sua aplicação exige muito esforço, especialmente no que diz respeito à organização e administração das atividades, por parte do docente responsável. O que, por muitos, pode ser visto como uma limitação da estratégia, entretanto nossos resultados indicam que seu uso, se bem planejado, gera benefícios substanciais para os alunos.

\section{Referências}

ARONSON, E. The jigsaw classroom. Beverly Hills: Sage, 1978.

BARBOSA, R. M. N.; JÓFILI, Z. M. S. Aprendizagem cooperativa e ensino de química - parceria que dá certo. Ciência \& Educação, v. 10, n. 1, p. 55-61, 2004.

BRASIL, Ministério da Educação. Diretrizes Curriculares Nacionais para os Cursos de Química. Parecer N CNE/CES 1.303/2001. Brasília: MEC, 2001.

COCHITO, M. I. S. Cooperação e aprendizagem: educação intercultural. Lisboa: ACIME, 2004. 
EILKS, I. Experiences and reflections about teaching atomic structure in a jigsaw classroom in lower secondary school chemistry lessons. Journal of Chemical Education, v. 82, n. 2, p. 313-319, 2005.

FATARELI, E. F. FERREIRA, L. N. A. F.; FERREIRA, J. Q.; QUEIROZ, S. L. Método cooperativo de aprendizagem jigsaw no ensino de química. Química Nova na Escola, v. 32, n. 3, p. 161-168, 2010.

FOURLAS, G.; WRAY, D. Children's oral language: a comparison of two classroom organisational systems. In: WRAY, D. (Org.) Emerging partnerships, Current research in language and literacy. Clevedon: Multilingual Matters, 1990. p. 76-86.

HAGEN, J. P. Cooperative learning in organic II. Increased retention on a computer campus. Journal of Chemical Education, v. 77, n. 11, p. 1441-1444, 2000.

JOHNSON, D. W., JOHNSON, R.T. Cooperation and competition: theory and research. Edina: Interaction Book Company, 1989.

JOHNSON, D. W.; JOHNSON, R. T.; HOLUBEC, E. J. Los nuevos círculos del aprendizaje: la cooperación en el aula y la escuela. Virginia: Aique, 1999.

KUMPULAINEN, K.; MUTANEN, M. The situated dynamics of peer group interaction: an introduction to an analytic framework. Learning and Instruction, v. 9, p. 449-473, 1999.

KUMPULAINEN, K. The nature of children's oral language interactions during collaborative writing experience at the computer. Tese de doutorado - University of Exeter, Exeter, 1994.

MASSI, L.; CERRUTTI, B. M.; QUEIROZ, S. L. Metodologia de ensino jigsaw em disciplina de química ambiental. Química Nova, v. 36, n. 6, p.897-904, 2013.

TEODORO, D. L.; PAGOTTO, J. F., MOTHEO, A. J.; QUEIROZ, S. L. Formação docente no ensino superior de química: contribuições dos programas de aperfeiçoamento de ensino. Química Nova, v. 34, n. 4, p.714-719, 2011.

VALVERDE, G. J.; VIZA, A. M. L. Optimización metodológica de entornos telemáticos cooperativos (BSCW y SINERGEIA) como recursos didácticos de la química en la producción de hipermedia. Enseñanza de las Ciencias, v.26, n.1, p. 93106, 2008.

ZUCCO, C.; PESSINE, F. B. T.; ANDRADE, J. B. Diretrizes curriculares para os cursos de química. Química Nova, v.22, n.3, p.454-461, 1999.

DANIEL LINO TEODORO. Licenciado em Química pela Universidade Federal de São Carlos e Mestre em Química pelo Instituto de Química de São Carlos, Universidade de São Paulo. É professor do Centro Universitário Adventista de São Paulo e doutorando do Programa de Pós-Graduação em Química do Instituto de Química de São 
Carlos, Universidade de São Paulo. Tem experiência na área de Educação em Química, com ênfase em aprendizagem cooperativa e colaborativa.

PATRÍCIA FERNANDA DE OLIVEIRA CABRAL. Licenciada em Química pela Universidade Federal de Alfenas e mestranda do Programa de Pós-Graduação em Química do Instituto de Química de São Carlos, Universidade de São Paulo. Atuou como professora efetiva da rede estadual de ensino do Estado de São Paulo e tem experiência na área de Educação em Química, com ênfase em aprendizagem colaborativa suportada por computador.

SALETE LINHARES QUEIROZ. Química Industrial pela Universidade Federal do Ceará, Mestre em Química pela Universidade Federal de São Carlos e Doutora em Química pela Universidade Estadual Paulista Júlio de Mesquita Filho. É bolsista de produtividade em pesquisa do $\mathrm{CNPq}$, coordenadora do Curso de Especialização em Educação em Ciências lato sensu da Universidade de São Paulo, vice-diretora do Centro de Divulgação Científica e Cultural da Universidade de São Paulo e editora da Revista Química Nova na Escola (Sociedade Brasileira de Química). Atua como Professora do Instituto de Química de São Carlos, Universidade de São Paulo, onde coordena o Grupo de Pesquisa em Ensino de Química, no qual foram formados, até o momento, sob a sua orientação, dezessete mestres e cinco doutores. Tem experiência na área de Educação em Química, com ênfase em linguagem, novas tecnologias e estado da arte no ensino de química.

Recebido: 24 de junho de 2014

Revisado: 30 de novembro de 2014

Aceito: 06 de janeiro de 2015 